Available online at $\quad$ http://www.jfas.info

\title{
METHODOLOGY FOR NEW PRODUCT DEVELOPMENT BASED ON FORMALIZATION OF ENGINEERING PROCESS
}

\author{
Y. P. Rakunov \\ Ph.D. in Technical Sciences, Associate Professor National Research University Moscow State \\ University of Civil Engineering, Russia
}

Published online: 08 August 2017

\begin{abstract}
The purpose of this paper was to define an algorithm of an engineering process throughout the product life cycle using computer-aided design systems. A flow chart of the 1st stage of an engineering design by means of an automated data retrieval database is shown. Stages of the creation of a new product and a formalization structure of engineering process are described. The paper analyzes the concept of an engineering design as an evolutionary and creative thinking which combines a scientific approach and creativity based on intuition. It was proved that an ability to design is both science and art. In the same manner as science is inseparable from art, and analysis is connected with synthesis, evolutionary changes are synchronized with the advent of new things.
\end{abstract}

Keywords: engineering design, process stages, structure of a process, production manager, ability to design, evolution, creation of new things, science and art.

\section{INTRODUCTION}

The process of engineering design starts after the finalization of an overall objective that has to be achieved as a result of the material implementation of a designed object [1-4]. The process of engineering design can be represented as a closed feedback iterative sequence. Task clarification (design specification) -synthesis (inventive activities), engineering analysis and calculation -decision-making [5-7].

Author Correspondence, e-mail: rakunov1991@mail.ru

doi: $\underline{\text { http://dx.doi.org/10.4314/jfas.v9i2s.867 }}$ 


\section{METHODOLOGICAL FRAMEWORK}

For example, let's consider a task of designing a device for quick preparation of design documentation and a task of designing a system (devices) that automates the manufacture of different parts (including growth by prototyping).

The first stage of an engineering design (stage of analysis) is the search for possible solutions for the task. This stage involves a selection of the optimum approach to achieve an objective, whether it is a known approach or a completely new one (generation of an approach or an implementation technology). Thus, in the first example, a device for quick preparation of design documentation can utilize methods of drawing of documents using electromechanical, electrochemical, electronic, thermal, and other techniques. In the second example, in the technological system, which is designed to automate the manufacturing of parts, it is possible to use the following methods: casting, hot die forging, cold sheet stamping, laser nesting, water jet cutting, machining, surface plastic hardening, pulse machining, etc.

After a decision about the optimum approach to proceed is made, this stage results in a more detailed description of the task which needs to be completed to achieve an overall objective. Then, a schematic diagram of an object is selected based on the fundamental idea represented as an original or known approach, which is used in a new way to design a predefined object. An engineering analysis and calculation of the selected option are carried out at the next stage (Fig. 1).

After the analysis, it is supposed that an analytical or experimental model is created, which is used to obtain quantitative evidence to make sure that the schematic diagram of a product (device) meets the requirements of the design specification considering all predefined parameters and constraints (for example, quality and performance, presence availability of equipment and tools, availability of qualified specialists and personnel for production). 


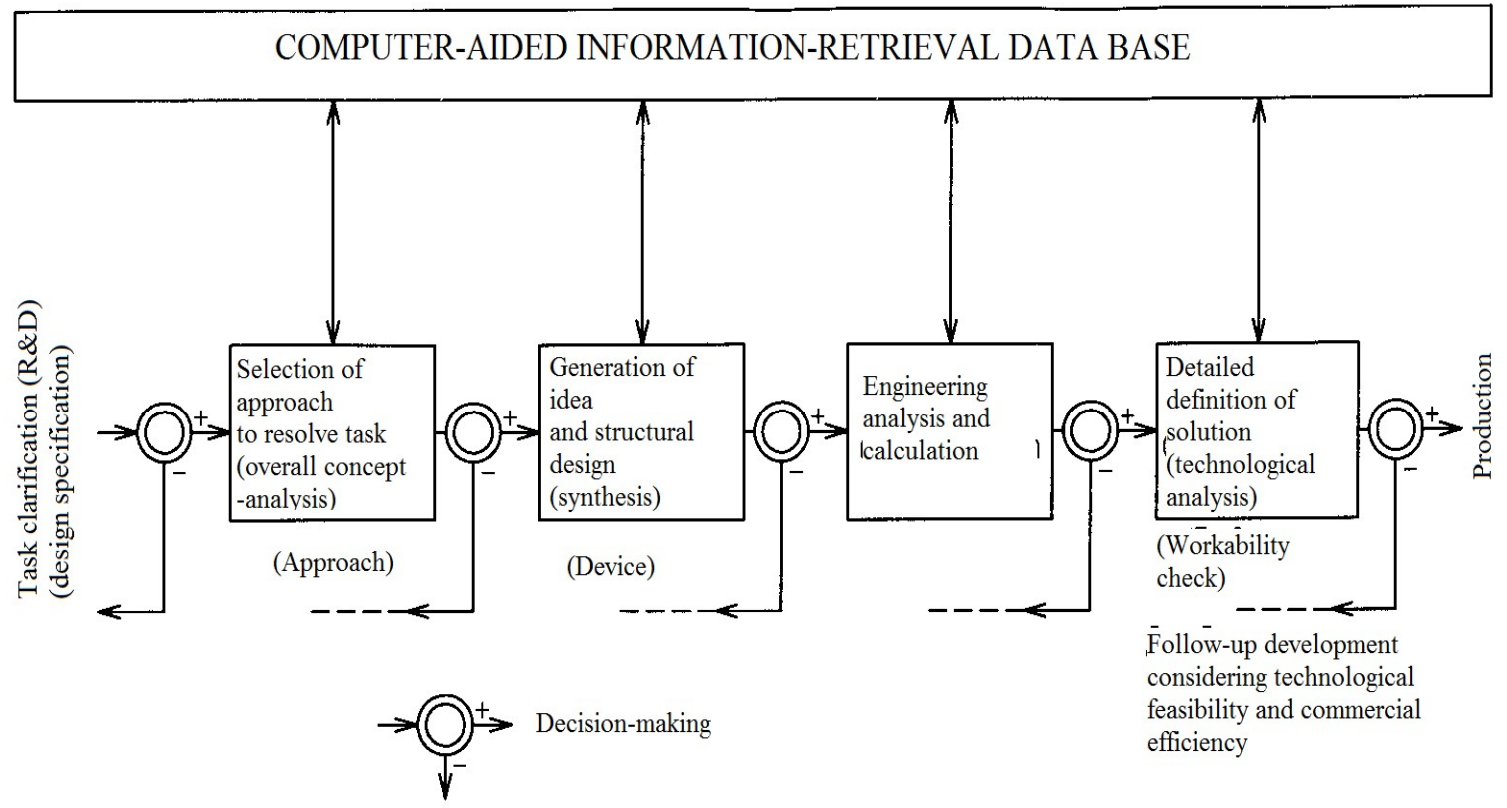

Fig.1. Flowchart of the $1^{\text {st }}$ stage of engineering design

A technological analysis is performed at the next (final) stage after the decision is made. This stage primarily focuses on the study and comparison of production capabilities (availability of tools and jigs, of standard and unified assemblies and components) and follow-up development of the structural design of a device taking into account such process capabilities. Then, the designed object is put into production (serial). A transition from one stage to another is characterized by the decision-making process (see Fig. 1). Any stage can repeat itself many times until a positive (optimum) decision is made. In essence, the design process reduces itself to the suggestion of an appropriate method, scheme, or idea and to the quantitative analysis of this suggestion [8-12].

The stage of synthesis of a technical solution is the basis of the design process. It is a good (adequate) idea (or several ideas) that eventually leads to a product with high performance values [13-15].

The process of development of a new product can be presented as a series of controlled (engineering and technical) processes (see Fig. 2).

1) Search for new ideas, receipt of ideas from internal or external sources;

2) Screening of ideas.Elimination of ideas which are obviously inconsistent with goals and possibilities of a company. This is done by company managers as they have the deepest understanding of objectives and tasks of a manufacturer. 
3)

Product development.Design engineering and check at all stages, starting from an idea presented in a paper form (or electronic drawing) and finishing with a ready product. A precise definition is given to standard size, performance parameters, shape, weight, the purpose of a product, its patentability, materials and methods of related machining, process jigs and tools, operational expenses, and servicing procedure. In essence, this stage of research and development presents a relatively small part of the program of a new product development because, usually, the outcome of the research is knowledge, while the outcome of the development is a prototype sample.

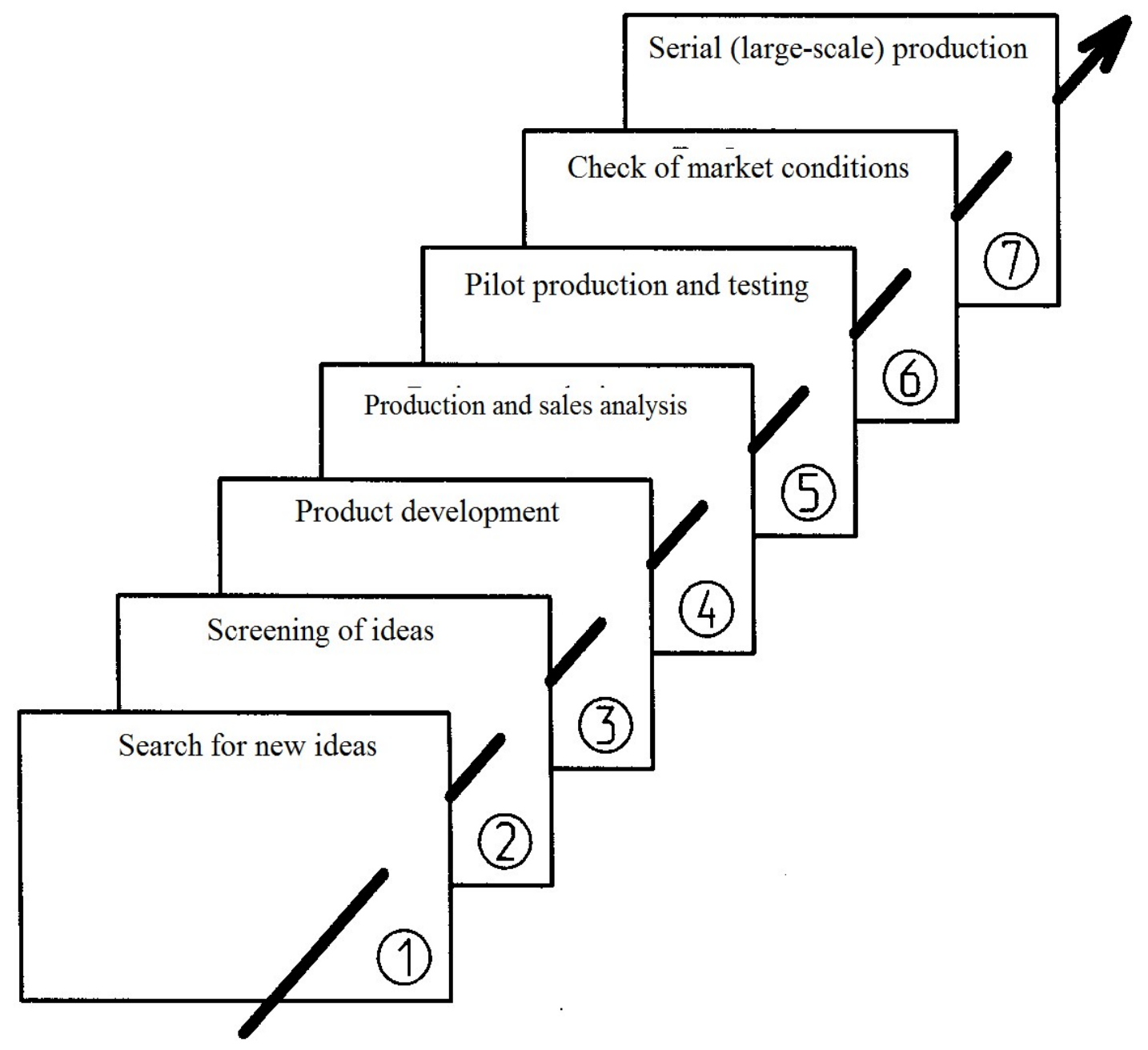

Fig.2. Stages of a new product creation 
4) Business analysis.Transition from ideas to specific recommendations, including the development of an initial program of product creation. The program encompasses the following aspects:

-check of a created product for competitiveness and assessment of market potential;

-determination of manufacturing requirements, of primary and auxiliary equipment;

-determination of financial expenses required for the final development of a product;

-determination of product distribution channels.

5) Pilot production.A relatively small number of products (a defined batch) is manufactured at the production line to check:

- qualifications of performers (personnel);

-quality control and maintenance;

-accuracy and reliability of tools and holding equipment;

-time required to manufacture a product;

-prime cost.

The pilot production is used to work out the technology for serial production of the product [16-17].

6) Check of market conditions.A segment of the market is selected where experimental products are sold. Sales specialists study a product demand (reaction of customers), competitiveness of a product, and a circle of customers. Such market exercises shall be carried out before a decision to start serial production, and even more so, large-scale production is made.

7) Serial (large-scale) production. After a thorough study of the results obtained at the previous stages, a production and sales program is drawn up. From this point forward, the reputation of a company and its resources depend on a new product. Throughout this period, managers of the company shall continuously collect and process all data which contribute to the improvement of a product, its production technology, and implementation approaches.

\section{RESULTS}

Talent and creativity of engineering personnel are the key factors required to transform an idea into a new product which is successful, meets the criteria of its production and sales, is of high quality at minimum costs, and is delivered to a customer in a timely fashion. Time and money required to design and develop a new product are directly related to the effectiveness of an idea and to the successful utilization of known structural materials and advanced process technologies. 
Development of a product is a process of design, or an iterative cybernetic system with direct and feedback communications. The development process falls under the cognizance of engineering personnel (Fig. 3).

According to the design specification, the design includes engineering, calculation and structural analysis of a breakdown scheme (a list of assembly units), working elements, and particularly complex and critical parts, as well as prototype tests. Engineering is the most critical stage as it is used to define standard size, physical shape, and technical characteristics of a product, as well as to check feasibility (practicability) of a technical solution. To ensure success at this stage, the related work shall be given to qualified design engineers who need to know and understand--and, at small companies, even implement--the duties of a structural designer, designer, researcher of technical solutions, draftsman, modeler, test engineer, economic analyst, material scientist, and process engineer [22-25].

Calculation and structural analysis are required to check if it is possible to implement an idea. Intuitive solutions often lead to high costs because trial and error methods require a lot of resources. Therefore, it is necessary to distinguish such solutions from the formalized explicit evaluation which is based on calculations of optimum utilization of tools, materials, equipment, and work force. These calculations make it possible to determine whether characteristics of a product comply with performance predictions outlined in the design specification. Testing of a prototype sample is the most expensive stage because it requires a specially prepared place and equipment. Therefore, it is necessary to make a thoughtful planning. Tests make it possible to confirm technical parameters, detect defects of a product under normal operating conditions, and check a required resource of a product.

The next stage of the product creation is the development of a commercial technological process. It includes the below three phases (see Fig. 3):

1) the arrangement of information, material, and energy flows;

2) management of an enterprise and of enterprise resources;

3) manufacture of a product according to a process route. 
U
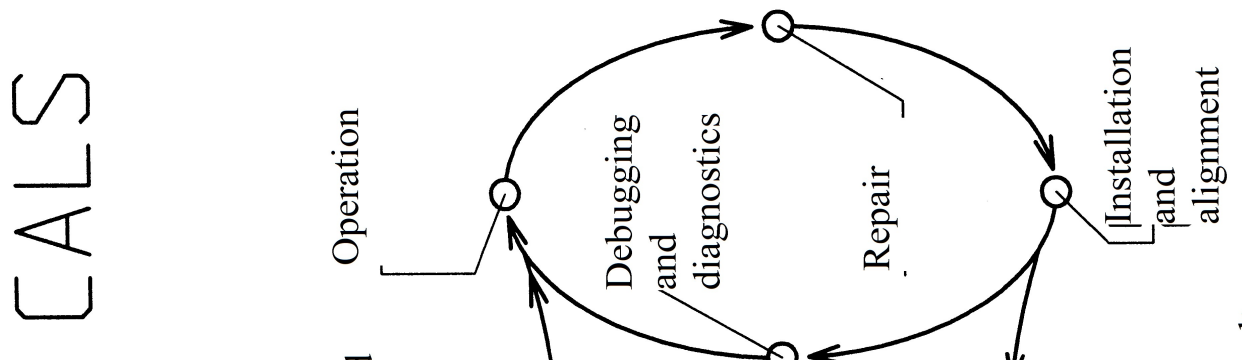

$\sum_{1}$

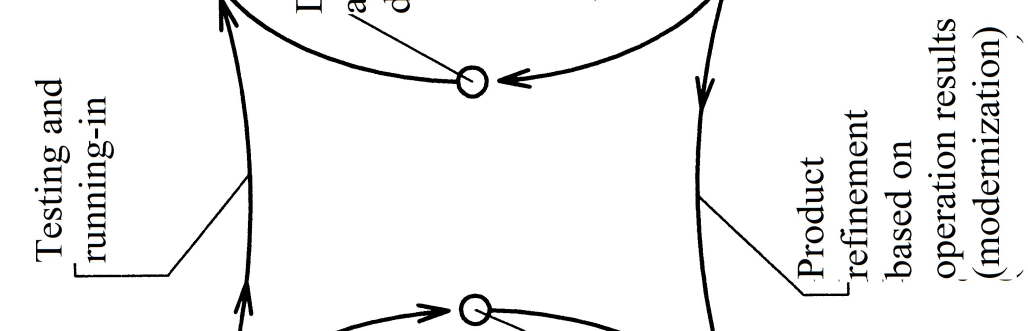

$+$

$\square$

$\square$
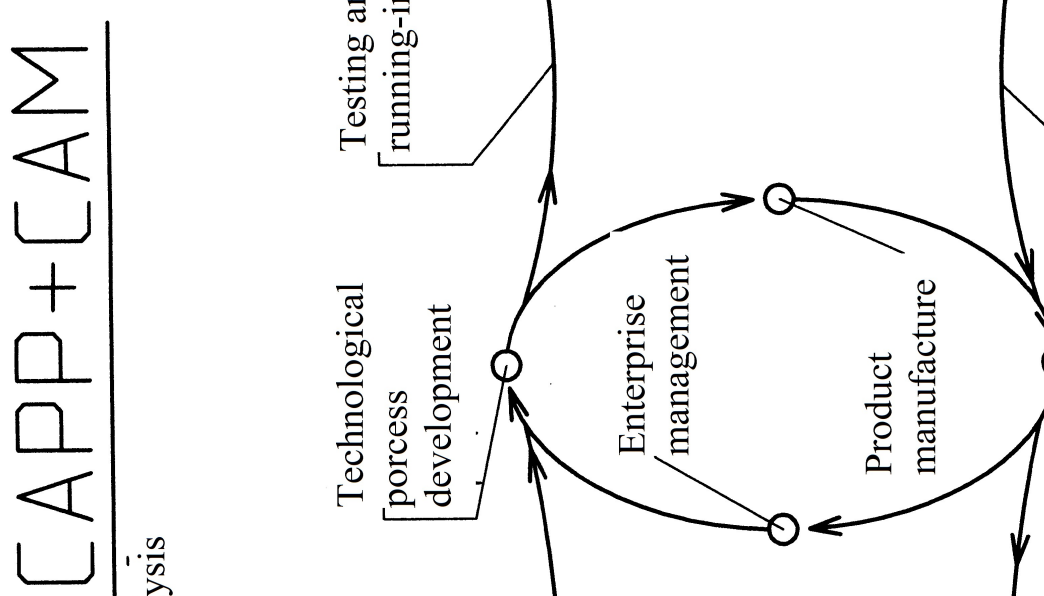

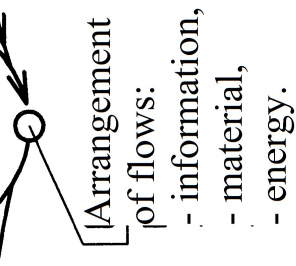

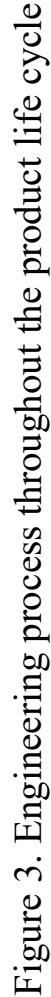

$+$

$\sqcup$

$\varangle$

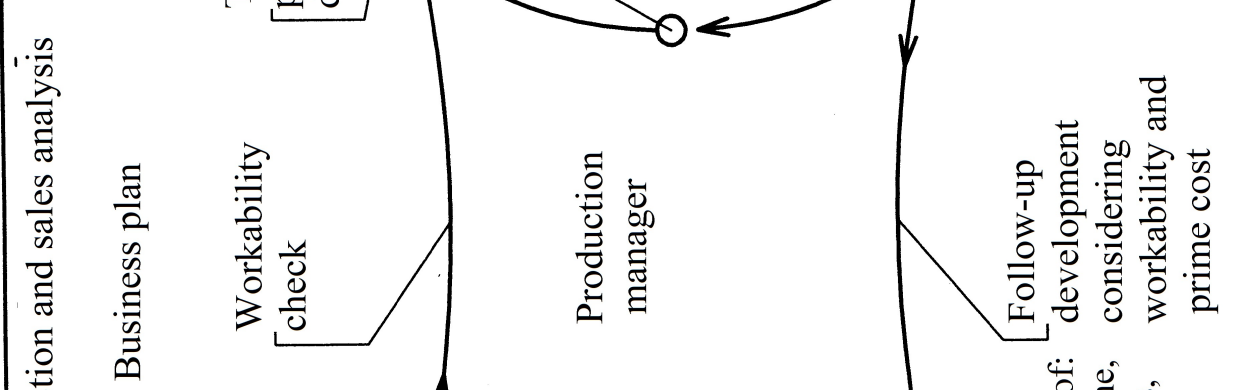

$\square$.0ี

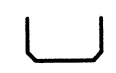

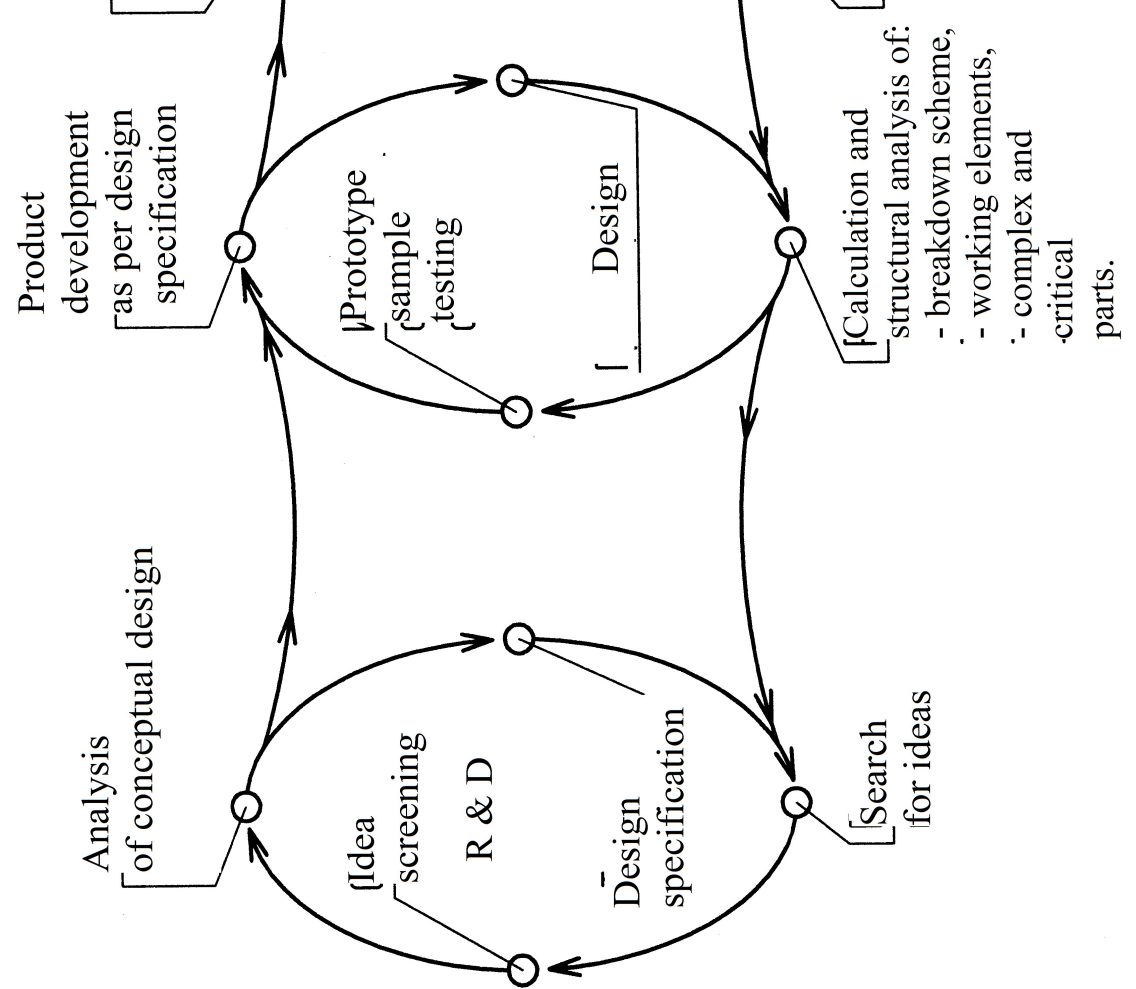


In close cooperation with a design engineer, a process engineer develops a technology for product manufacture and quality control (engineers may have conflicting opinions but always need to reach a compromise). The process engineer chooses equipment, machines, and accessories which are necessary to make sure that the product meets technical conditions and requirements of customers (clients) and of the market.

The material flow includes procurement, receipt, and handling of all materials to be used during product manufacture, as well as storage and transportation of ready products.

Management of an enterprise is one of the most complex activities in terms of formalization and forecasting because it is required to select and process huge amounts of data, ensure professional training and distribution of personnel, and control availability of workforce, integrity of equipment, and the above-mentioned flows.

A production manager is responsible for the management of an enterprise during the creation of a new product. Development of a technological process shall be linked with the development and design of a product. This approach saves time, resources, and money and leads to the improvement of manufactured products. Also, while in operation, it allows us to get an idea about what kinds of new products satisfy modern production and sales requirements. The technological process will be developed in the most efficient way if all involved parties have exhaustive information about new improvements and changes in the model of a product introduced by an engineering department.

To reconcile interests of many functional departments involved in the creation of new products, company management shall clearly define responsibilities for the development process, minimize the number of working contacts, and establish functional and informational relations. Therefore, it is expedient to prepare work tasks and revise them on a regular basis (monthly) during the initial stages of reorganization. Managers shall employ effective methods to enforce schedules for proper planning of events and stages.

Ideas shall be selected based on clearly defined specific objectives of a company. That said, consideration must be given to the level of costs acceptable during the creation of a new product. The level of costs is determined by several factors, such as work force, production capacity and area, materials, market channels (trade companies), as well as by the plans of a company to reproduce the range of products (services) or to expand it (up to a standard series).

Managers shall evaluate production capabilities and commercial opportunities before time and money are allocated for the development of a new product. Shallow analysis usually leads to unsuccessful products. It happens because under-explored aspects are often excluded from the 
analysis when a company, which starts to develop new products, does not have reliable data on production and sales. The higher the level of originality of a product, the more difficult it is to carry out an analysis. Successful analysis requires thorough and complete research of the market (its trends, capacity, a level of competitiveness), profit opportunities, consumer needs, and statistics reflecting consumer opinion on the new product.

\section{DISCUSSIONS}

To design means to create, to produce something new. Engineering design is a continuous process throughout which scientific and technical information is used to create a new system, device, or method that provide benefits to the society. As a result of the design, we shall receive products that ensure profit-making.

An ability to make the design is both science and art. Taken as science, it is possible to comprehend the design by studying regularly, accumulating experience, and solving problems. Taken as art, the design requires hard work and complete commitment from those who try to master this skill. The design implies the use of analysis and synthesis as two methods of obtaining scientific knowledge $[4,5,18,19]$.

Sometimes, an analysis is identified with the design because people think that carrying out of a good analysis presupposes good design. Analysis (differentiation), i.e. a breakdown of the reviewed task into controlled stages and further study of each stage, is carried out during the design to check the goal which was set at the beginning. Synthesis (integration), i.e. combining of elements into a unified whole, is closer to the design than any other process. However, synthesis should be a creative process to make an original combination of joined elements. Throughout the design process, science and art, analysis and synthesis are inseparable and operate at the same time $[9,16,17]$.

When designing a system, device, or a process, it is possible to rely on one of the below principles: 1) evolution or 2) creation. Currently, the design is more than ever associated with the continuous creation of new products. Owing to the rapid growth of the number of scientific and technical discoveries and to the high level of marketing competition between companies, the creation of new products moves to the forefront and strongly requires the implementation of technical innovations. In this case, it might not be sufficient for a design engineer to have creative skills and analytical abilities because of the absence of experience used as the basis for decision-making. Therefore, such practices of designing are subject to big risks. From the very beginning, a design engineer shall think about creating something new and search for an original viable idea. In the same manner as science is inseparable from 
art, and analysis is connected with synthesis, evolutionary changes are synchronized with the advent of new things.

\section{CONCLUSIONS}

The first step of the design procedure is to obtain information about the current state of the subject area, technical devices, materials, methods (tools) of fabrication, components, technological process, market conditions, etc.

As the work over the project progresses, a design engineer constantly compares his/her ideas with the previous and current state of knowledge on the subject. The design can aim for the future but its results shall be based on the previous knowledge to ensure continuity of structures and concepts. Thus, a design engineer creates something new and makes evolutionary changes at the same time.

A great success in the design can be attained by a person who has the below-listed qualities acquired through education, including self-education, and through self-discipline and love for creativity:

1) competence, a design engineer shall know physical laws and basics of mathematics;

2) expertise, a design engineer shall develop and improve analytical and graphic techniques of problem-solving, practices of experimental work;

3) involvement, a design engineer shall demonstrate intellectual curiosity, use fair practices in scientific matters, take responsibility for developed structures and concepts, be willing to make decisions, be able to lay and defend his/her ideas and conclusions based on experience;

4) creativity, a design engineer shall try to achieve originals results and look for spheres of applications for devices (structures), be willing to avoid traditional (trivial) solutions and be confident that there is a creative solution.

\section{REFERENCES}

[1] Jones J. Ch. Design Methods [Metody proyektirovaniya]. Translation from English. Moscow: Mir publishing house, 1986. P. 322.

[2] Databases of intellectual systems [Bazy dannykh intellektualnykh system]. Gavrilova T.A. Khoroshevskiy V.F. St.-Petersburg: Piter publishing house, 2001. P. 384.

[3] Automation of search-based engineering: artificial intelligence in machine-building design [Avtomatizatsiya poiskovogo konstruirovaniya: iskusstvennyy intellekt $\mathrm{v}$ 
mashinostroitelnom proyektirovanii]. Polovinkin A.I. et al, General editorship of А.И. Polovinkin A.I. Moscow: Radio i svyaz publishing house, 1981. P. 344.

[4] Abramov V.V., Rakunov Yu.P., Gerasimenko V.B., Suetina T.A. Technical basis for creation of machines and equipment for production of construction materials, products, and structures [Tekhnicheskiye osnovy sozdaniya mashin i oborudovaniya proizvodstva stroitelnykh materialov, izdeliy i konstruktsiy]. Moscow: Granitsa publishing house, 2009. P. 432.

[5] Bykov V.V., Bykov V.P. Design study in machine-building [Issledovatelskoye proyektirovaniye v mashinostroyenii]. Moscow: Mashinostroyeniye publishing house, 2011. P. 256.

[6] Akulovich L.M. Basics of computer-aided design of technological processes in machinebuilding [Osnovy avtomatizirovannogo proyektirovaniya tekhnologicheskikh protsessov $\mathrm{v}$ mashinostroyenii]. Training manual. Akulovich L.M., Sheleg V.M. Minsk: Novoye znaniye publishing house. Moscow: INFRA-M publishing house, 2012. P. 488. (Higher education).

[7] Brekhovskikh S.M., Prasolov A.P., Solinov V.F. Functional computer-aided systematics of materials, machines, products, and technologies [Funktsionalnaya kompyuternaya sistematika materialov, mashin, izdeliy i tekhnologiy]. Moscow: Mashinostroyeniye publishing house, 1995. P. 552.

[8] GOST R ISO 10303-1-99. Production automation systems and their integration. Submission of product data and data exchange [Sistemy avtomatizatsii proizvodstva i ikh integratsiya. Predstavleniye dannykh ob izdelii i obmen etimi dannymi]. Moscow: Gosstandard RF publishing house, 2000.

[9] Ditrikh Ya. Design and construction: System approach [Proyektirovanie i konstruirovanie: Sistemnyy podkhod]. Translation from Polish. Moscow: Mir publishing house, 1981. P. 456.

[10] Yevgenyev G.B. Sistematology of engineering knowledge [Sistemologiya inzhenernykh znaniy]. Training manual for institutions of higher education. Moscow: Bauman MGTU publishing house, H.Э. 2001. P. 376.

[11] Intellectual systems for making design solutions [Intellektualnye sistemy prinyatiya proyektnykh resheniy] Alekseyev A.V., Borisov A.N., Vilyums E.V et al. Riga: Zinatne publishing house, 1997. P. 260.

[12] Kolchin A.F., Ovsyannikov M.V., Strekalov A.F., Sumarokov S.V. Product life cycle management [Upravleniye zhiznennym tsiklom produktsii]. Moscow: Anakharsis publishing house, 2002. P. 304. 
[13] Kraynev A.F. Ideology of engineering [Ideologiya konstruirovaniya]. Moscow: Mashinostroyeniye-1 publishing house, 2003. P. 384.

[14] Norenkov I.P. Basics of computer-aided design [Osnovy avtomatizirovannogo proyektirovaniya]. Textbook for institutions of higher education. $2^{\text {nd }}$ edition, revised and enlarged. Moscow: Bauman MGTU publishing house, H.Э. 2002. P. 376.

[15] Solnitsev R.I. Information technologies in design [Informatsionnye tekhnologii $\mathrm{v}$ proyektirovanii]. MVO RF, State University of Aerospace Instrumentation publishing house, 2000. P. 360.

[16]Rakunov Yu.P. Development of the system of multi-level basic technology // High-end technologies in machine-building [Razrabotka sistemy mnogourovnevoy bazovoy tekhnologii // Naukoemkiye tekhnologii v mashinostroyenii]. No. 1, 2012. P. 40-46.

[17]Rakunov Yu.P. Subsystem for synthesization of multi-level basic technology // High-end technologies in machine-building [Podsistema sintezirovaniya mnogourovnevoy bazovoy tekhnologii // Naukoemkiye tekhnologii v mashinostroyenii]. No. 10, 2012. P. 36-46.

[18] Hill P. The science of engineering design [Nauka $\mathrm{i}$ iskusstvo proyektirovaniya]. Translation from English. Mir publishing house, 1973. P. 270.

[19] Hubka V. Theory of technical systems [Teoriya tekhnicheskikh sistem]. Translation from German. Moscow: Mir publishing house, 1987. P. 208.

[20] Jorgensen E. DoD classes of electronic technical manuals. // Naval surface warfare center. 1994.

[21] Giffler B., Thompson G. Algorithms for Solving Production-Scheduling Problems // Operat. Res. 1964. N 2.

[22] Blanton J., Wainwright R. Multiple Vehicle Routing with Time and Capacity Constraints Using Genetic Algorithms // Proc. of $5^{\text {th }}$ Int. Conf. on GA. Morgan Kaufmann Publ., San Mateo. 1993.

[23] Walsh N. A Technical Introduction to XML. // http://www.arbortext.com/Think_Tank/

XML_Resources/

[24]http://www-3.ibm.com/solutions/engineering/esenovia.nsf/

[25] Mackrell J. Supporting Collaborative Product Definition via Scaleable, Web-based PDM. Prepared by CIM-data, Inc. 2000.

How to cite this article:

Rakunov Y P. Methodology for new product development based on formalization of engineering process. J. Fundam. Appl. Sci., 2017, 9(2S), 1662-1673. 